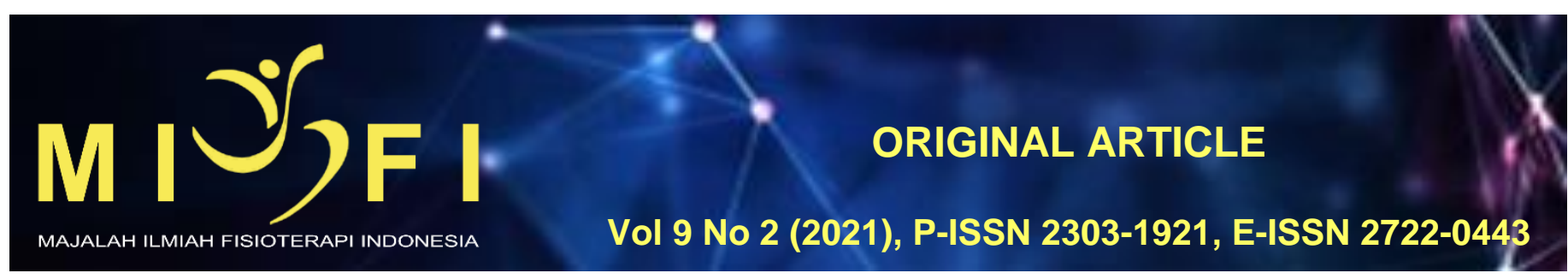

\title{
HUBUNGAN KETEPATAN PENGGUNAAN BABY WALKER TERHADAP PERKEMBANGAN MOTORIK KASAR ANAK USIA 15-18 BULAN DI DENPASAR TIMUR
}

\section{Anak Agung Sagung Dhriti Anggita Saraswati Arnaya ${ }^{1}$, I Made Niko Winaya ${ }^{2}$, Nila Wahyuni ${ }^{3}$}

${ }^{1}$ Program Studi Sarjana Fisioterapi dan Profesi Fisioterapi, Fakultas Kedokteran, Universitas Udayana, Denpasar, Bali 2Departemen Fisioterapi, Fakultas Kedokteran, Universitas Udayana, Denpasar, Bali

${ }^{3}$ Departemen IImu Faal, Fakultas Kedokteran, Universitas Udayana, Denpasar, Bali anggitaarnaya@gmail.com

\begin{abstract}
ABSTRAK
Dalam menunjang kemampuan motorik kasar pada anak dapat dilakukan dengan pemberian stimulasi yaitu baby walker. Tujuan dari penelitian ini yaitu untuk menganalisis hubungan ketepatan penggunaan baby walker terhadap perkembangan motorik kasar anak usia 15-18 bulan di Denpasar Timur. Rancangan yang digunakan dalam penelitian ini adalah observasional analitik dan dengan desain penelitian cross sectional. Penelitian ini dilakukan di wilayah kerja Puskesmas I Denpasar Timur yang dilakukan pada bulan April-Mei 2019. Teknik pengambilan sampel pada penelitian ini menggunakan teknik Purposive sampling, dengan jumlah sampel yaitu 33 anak (18 laki-laki dan 15 perempuan) usia 15-18 bulan. Untuk mengetahui hubungan ketepatan penggunaan baby walker terhadap perkembangan motorik kasar anak usia 15-18 bulan di Denpasar Timur menggunakan uji statistik chi square Dalam penelitian ini diperoleh nilai $p=$ 0.000 ( $p<0.05)$. Semakin tepat anak menggunakan baby walker maka perkembangan motoriknya cenderung sesuai dengan usianya karena dengan penggunaan baby walker yang tepat dapat menyebabkan otot-otot ekstremitas bawah anak seperti otot hamstring dan otot gastrocnemuis menjadi terlatih dan lebih kuat, selain otot ekstremitas bawah penggunaan baby walker yang tepat juga dapat memperkuat otot-otot core stability pada anak, sehingga ketika otot anak menjadi lebih kuat maka perkembangan motoriknya juga akan semakin baik dan sesuai dengan usianya .Berdasarkan penelitian yang telah dilakukan tentang hubungan ketepatan penggunaan baby walker terhadap perkembangan motorik kasar anak usia 15-18 bulan di Denpasar timur dapat disimpulkan bahwa terdapat hubungan yang signifikan antara ketepatan penggunaan baby walker dengan perkembangan motorik kasar anak
\end{abstract}

Kata Kunci: Baby Walker, Motorik Kasar, Ketepatan

\section{THE CORRELATION BETWEEN ACCURACY OF USING BABY WALKER ON CHILD'S GROSS MOTOR DEVELOPMENT AT AGE 15-18 MONTH IN DENPASAR TIMUR}

\begin{abstract}
To support hard motor development on child can use baby walker. The purposed of this study is to analyzed the correlation between accuracy of using baby walker on child's motor development at age 15-18 month in Denpasar Timur. These studies used observational analytic and cross-sectional design. The studies are located at Puskesmas I Denpasar Timur work zone in april-may 2019. On these studies to get the sample used purposive sampling technique with total sample 33 child (18 male and 15 female) on age 15-18 month. This studies also used chi square statistic test to prove there is a correlation between accuracy using baby walker on child's motor development at age 15-18 month in Denpasar Timur. The $p$ result of this study is $p=0.000(p<0.05)$. If the child properly using baby walker, then it will impact skilled of lower extremity muscles like gastrocnemius and hamstring stronger, beside that by using baby walker correctly can raise core stability muscle stronger and more stable, so it can increase hard motor skill of the child growth according to their age. Based on those studies, the conclusion is there is a significant correlation between accuracy of using baby walker on child motor development at age 15-18 month in Denpasar Timur
\end{abstract}

Key Words: Baby Walker, Hard Motor Development, Accuracy

\section{PENDAHULUAN}

Proses tumbuh kembang anak merupakan hasil interaksi faktor genetik dan faktor lingkungan ${ }^{1}$. Tumbuh kembang anak dipengaruhi oleh kemampuan sensorik dan kemampuan motorik. Perkembangan motorik anak merupakan salah satu hal wajib yang harus dimiliki dan dipenuhi oleh anak. Saat ini banyak orang tua yang mengeluhkan tentang keterlambatan proses perkembangan motorik anak khususnya keterlambatan dalam hal kemampuan berjalan, hal tersebut baru disadari oleh orang tua ketika anak mereka menginjak usia 15-18 bulan tetapi belum mampu untuk berdiri secara mandiri atau belum bisa berjalan dan berlari secara seimbang ${ }^{2}$. Umumnya keterlambatan perkembangan motorik yang dialami anak dapat terjadi karena kurangnya pemberian stimulasi dan juga kurangnya asupan gizi yang diperoleh oleh anak ${ }^{3}$. Keterlambatan perkembangan motorik yang dialami oleh anak memiliki beberapa dampak negatif seperti, keterlambatan motorik anak dapat menimbulkan gangguan sistem vestibular atau keseimbangan pada anak dan keterlambatan motorik anak juga dapat menyebabkan otot-otot anak menjadi melemah bahkan dapat menyebabkan otot anak menjadi atrofi ${ }^{4}$. Sebanyak $25 \%$ anak dengan rentang usia $6-18$ bulan di Amerika mengalami gangguan keseimbangan dan kelemahan otot akibat keterlambatan motorik ${ }^{5}$, dari data yang 
diperoleh oleh Kementrian Kesehatan Indonesia menyebutkan bahwa sebanyak 11,5\% anak usia 15-18 bulan di Indonesia mengalami gangguan keseimbangan dan kelemahan otot akibat keterlambatan motorik ${ }^{6}$, sedangkan menurut penelitian yang dilakukan oleh Supartha $\mathrm{M}$, et al menyebutkan bahwa jumlah anak usia 9-18 bulan yang mengalami gangguan keseimbangan dan juga kelemahan otot akibat keterlambatan perkembangan motorik di Provinsi Bali diperkirakan mencapai angka 6\%-13\%7.

Proses belajar berjalan pada anak berdasarkan tabel Denver Developmental Screening Test (DDST) sudah harus bisa dilakukan pada usia 15-18 bulan. Untuk menunjang proses berjalan pada anak dapat dilakukan dengan memberikan bantuan berupa stimulasi pada anak. Salah satu stimulasi yang dapat diberikan untuk menunjang perkembangan motorik anak menuju proses berjalan yaitu dengan pemberian baby walker. Pemberian baby walker dapat melatih otot-otot ekstrimitas bawah pada anak, selain itu, penggunaan baby walker juga mampu meningkatkan minat anak untuk segera bisa berjalan, sehingga hal tersebut dapat meningkatkan perkembangan motorik kasar anak dalam proses belajar berjalan. ${ }^{8}$

Pemilihan baby walker sebagai stimulasi perkembangan motorik kasar karena penggunaan baby walker dapat digunakan untuk melatih otot-otot ekstremitas bawah agar menjadi lebih kuat serta mampu menumpu berat badan dan dinilai sebagai media yang aman untuk menjaga anak agar tidak terjadi suatu cidera ${ }^{8}$.

Penggunaan baby walker dipercaya efektif untuk membantu anak berjalan lebih cepat, hal tersebut diperkuat oleh penelitian yang dilakukan oleh The European Child Safety Alliance menyebutkan bahwa anak yang menggunakan baby walker perkembangan motorik kasarnya dalam hal proses belajar berjalan akan lebih baik jika dibandingkan dengan anak yang tidak menggunakan baby walker ${ }^{9}$ tetapi hal tersebut bertentangan dengan penelitian yang dilakukan oleh Rehmani yang menyebutkan bahwa tidak terjadi perubahan yang signifikan dari penggunaan baby walker dalam menunjang perkembangan motorik anak, tetapi baby walker cenderung menyebabkan cidera pada anak ${ }^{10}$. Hal tersebut diperkuat oleh penelitian yang dilakukan Nariyanti E menyebutkan bahwa penggunaan baby walker yang terlalu lama akan berdampak buruk bagi perkembangan perkembangan motorik kasar anak, bahkan dapat mengakibatkan cidera pada anak ${ }^{11}$.

Berdasarkan hasil pertentangan beberapa penelitian tersebut, maka peneliti tertarik untuk meneliti tentang hubungan ketepatan penggunaan baby walker terhadap perkembangan motorik kasar anak usia15-18 bulan.

\section{METODE}

Rancangan yang digunakan dalam penelitian ini adalah observasional analitik dan dari segi waktu menggunakan desain penelitian cross sectional. Penelitian ini dilakukan di wilayah kerja Puskesmas I Denpasar Timur dan telah dilaksanakan pada bulan April 2019 sampai Mei 2019. Teknik pengambilan sampel pada penelitian ini menggunakan teknik Purposive sampling, pengambilan sampel dengan teknik ini dilakukan dengan cara menjadikan setiap anak yang berusia 15-18 bulan yang bertempat tinggal di wilayah kerja Puskesmas I Denpasar timur yang telah memenuhi kriteria inklusi dan eksklusi sebagai sampel penelitian. Pada penelitian kali ini didapatkan sampel sebanyak 33 orang sampel penelitian. Variabel independen pada penelitian ini yaitu ketepatan penggunaan baby walker, variable dependen pada penelitian ini yaitu perkembangan motorik kasar anak, variabel control pada penelitian ini yaitu usia dan status gizi anak, sedangkan variabel rambang dalam penelitian ini yaitu status sosial ekonomi, genetik, dan lingkungan prenatal postnatal.

Ketepatan penggunaan baby walker dinilai menggunakan kuesioner identifikasi baby walker multifunction, dimana hasil interpretasi pengukuran ketepatan penggunaan baby walker dilakukan dengan cara skoring yang dikategorikan menjadi 3 yaitu skor 28-30 tepat penggunaannya, 25-27 kurang tepat penggunaannya, <25 ada penyimpangan, oleh karena itu pengukuran ini termasuk skala ordinal.

Perkembangan motorik kasar anak usia 15-18 bulan dinilai berdasarkan kemampuan anak untuk berdiri dan berjalan sesuai dengan usianya dan dengan ataupun tanpa bantuan. Alat ukur yang digunakan adalah Kuesioner Praskrining Perkembangan Anak. Hasil interpretasi pengukuran kuesioner dilakukan dengan skoring dimana dikategorikan menjadi 3 yaitu skor 9-10 baik, skor 7-8 meragukan, dan skor $<6$ ada penyimpangan, pengukuran ini termasuk skala ordinal.

Analisa data yang digunakan pada penelitian ini yaitu analisis bivariat untuk mengetahui hubungan antara variabel independen dan variabel dependen menggunakan uji statistik chi square. Analisis univariat untuk mengetahui data deskriptif dari masing-masing variabel.

\section{HASIL}

Subjek pada penelitian ini adalah seluruh anak yang berusia 15-18 bulan yang bertempat tinggal di Wilayah kerja Puskesmas I Denpasar Timur yang telah memenuhi kriteria inklusi dan eksklusi sebanyak 33 subjek penelitian

Tabel 1. Distribusi Frekuensi Karakteristik Subjek Penelitian Berdasarkan Usia

\begin{tabular}{cccc}
\hline No & Usia & Jumlah $(\mathrm{n})$ & Persentase $(\%)$ \\
\hline 1 & 15 & 10 & 30.3 \\
2 & 16 & 5 & 15.2 \\
3 & 17 & 4 & 12.1 \\
4 & 18 & 14 & 42.4 \\
\hline & Total & 33 & 100 \\
\hline
\end{tabular}

Berdasarkan Tabel 1. diatas dapat dilihat penelitian ini didominasi oleh sampel penelitian berusia 18 bulan yaitu $42,4 \%$. 
Tabel 2. Distribusi Frekuensi Karakteristik Subjek Penelitian Berdasarkan Jenis Kelamin

\begin{tabular}{cccc}
\hline No & Jenis Kelamin & Jumlah $(\mathrm{n})$ & Persentase (\%) \\
\hline 1 & Laki-Laki & 18 & 54.5 \\
2 & Perempuan & 15 & 45.5 \\
\hline & Total & 33 & 100
\end{tabular}

Pada Tabel 2. diperoleh informasi, jenis kelamin sampel penelitian $54,5 \%$ adalah laki-laki dan $45,5 \%$ perempuan, yang berarti jumlah populasi subjek penelitian didominasi oleh anak laki-laki

Tabel 3. Distribusi Frekuensi Karakteristik Subjek Penelitian Berdasarkan tingkat sosial ekonomi

\begin{tabular}{cccc}
\hline No & Sosial Ekonomi & Jumlah $(\mathrm{n})$ & Persentase $(\%)$ \\
\hline 1 & Menegah ke bawah & 6 & 18.2 \\
2 & Menengah ke atas & 27 & 81.8 \\
\hline & Total & 33 & 100
\end{tabular}

Pada Tabel 3. dapat dilihat jika tingkat sosial ekonomi didominasi oleh anak dengan status sosial ekonomi menengah keatas yaitu $81,8 \%$.

Tabel 4. Distribusi Frekuensi Karakteristik Subjek Penelitian Berdasarkan Ketepatan Penggunaan Baby Walker

\begin{tabular}{cccc}
\hline No & Kategori & Jumlah $(\mathrm{n})$ & Persentase (\%) \\
\hline 1 & Tepat & 25 & 75.8 \\
2 & Kurang tepat & 1 & 3.0 \\
3 & Penyimpangan & 7 & 21.2 \\
\hline & Total & 33 & 100
\end{tabular}

Dari Tabel 4. dapat dilihat pada tabel tersebut bahwa didominasi oleh subjek menggunakan baby walker dengan tepat dengan persentase $75,8 \%$.

Tabel 5. Distribusi Frekuensi Karakteristik Subjek Penelitian Berdasarkan Perkembangan Motorik Kasar Anak

\begin{tabular}{cccc}
\hline No & Kategori & Jumlah $(\mathrm{n})$ & Persentase (\%) \\
\hline 1 & Sesuai & 26 & 78.8 \\
2 & Meragukan & 5 & 15.2 \\
3 & Penyimpangan & 2 & 6.0 \\
\hline & Total & 33 & 100
\end{tabular}

Berdasarkan Tabel 5. diatas dapat dilihat bahwa dari 33 anak yang menjadi sampel dalam penelitian ini, sebagian besar sampel penelitian sebanyak $78.8 \%$ mempunyai perkembangan motorik kasar yang sesuai dengan usianya.

Tabel 6. Hubungan Ketepatan Penggunaan Baby Walker Dengan Perkembangan Motorik Kasar Anak

\begin{tabular}{|c|c|c|c|c|c|c|c|c|c|c|}
\hline \multirow{4}{*}{ No } & \multirow{4}{*}{ Penggunaan Baby Walker } & \multirow{2}{*}{\multicolumn{6}{|c|}{ Perkembangan Motorik Anak }} & & & \multirow{4}{*}{$\mathrm{p}$} \\
\hline & & & & & & & & \multirow{2}{*}{\multicolumn{2}{|c|}{ Total }} & \\
\hline & & \multicolumn{2}{|c|}{ Penyimpangan } & \multicolumn{2}{|c|}{ Meragukan } & \multicolumn{2}{|c|}{ Sesuai } & & & \\
\hline & & $\mathrm{n}$ & $\%$ & $\mathrm{n}$ & $\%$ & $\mathrm{n}$ & $\%$ & $\mathrm{n}$ & $\%$ & \\
\hline 1 & Penyimpangan & 2 & 100 & 4 & 80.0 & 1 & 3.8 & 7 & 21.2 & \multirow{4}{*}{0,000} \\
\hline 2 & Kurang Tepat Penggunaan & 0 & 0 & 1 & 20.0 & 0 & 0 & 1 & 3.0 & \\
\hline 3 & Tepat Penggunaan & 0 & 0 & 0 & 0 & 25 & 96.2 & 25 & 75.8 & \\
\hline & Total & 2 & 100 & 5 & 100 & 26 & 100 & 33 & 100 & \\
\hline
\end{tabular}

Pada Tabel 6. dapat dilihat dari 33 anak yang menggunakan baby walker, didominasi oleh anak yang menggunakan baby walker secara tepat dan memiliki perkembangan motorik kasar yang sesuai dengan usianya yaitu sebanyak $75.8 \%$. Secara statistik dengan menggunakan uji Chi Square menunjukkan ada hubungan yang signifikan antara ketepatan penggunaan baby walker dengan perkembangan motorik kasar anak yaitu dengan nilai $p=0.000$ $(p<0.05)$.

\section{DISKUSI \\ Karakteristik Sampel}

Penelitian ini dilaksanakan pada bulan April-Mei 2019 di wilayah kerja Puskesmas I Denpasar Timur dengan jumlah total subjek penelitian anak usia 15-18 bulan sebanyak 33 anak. Pada tabel I dapat dilihat bahwa pada penelitian ini didominasi oleh anak usia 18 bulan yaitu diperoleh sebanyak 14 anak. Pada tabel II dapat dilihat untuk jenis kelamin subjek penelitian didominasi oleh anak yang berjenis kelamin laki-laki dengan jumlah 18 anak. Pada tabel III diketahui bahwa untuk tingkat sosial ekonomi subjek penelitian didapatkan untuk tingkat sosial ekonomi menengah kebawah yaitu sebanyak 18,2\% dan untuk sosial ekonomi menengah keatas diperoleh sebanyak $81,8 \%$. Menurut penelitian Tan et al tingkat sosial ekonomi dari orang tua akan mempengaruhi penggunaan baby walker sebagai penunjang perkembangan motorik anak ${ }^{12}$, selain itu tingkat sosial ekonomi orang tua tentunya juga akan mempengaruhi hal-hal yang akan menunjang perkembangan motorik anak seperti kebutuhan gizi anak ${ }^{1}$.

Pada tabel IV dapat dilihat bahwa mayoritas subjek penelitian menggunakan baby walker secara tepat yaitu sebanyak 25 anak (75,8\%), diperoleh juga anak dengan penggunaan baby walker yang kurang tepat sebanyak 1 anak $(3 \%)$, dan anak dengan penggunaan baby walker yang menyimpang sebanyak 7 anak $(21,2 \%)$. Berdasarkan penelitian 
Hasyim dikatakan bahwa penggunaan baby walker secara tepat dipengaruhi oleh faktor pendidikan dan pengetahuan orang tua ${ }^{13}$, selain itu tingkat sosial ekonomi seperti pendapatan orang tua juga dapat mempengaruhi penggunaan baby walker untuk menunjang perkembangan motorik anak ${ }^{12}$. Kurangnya pengawasan orang tua selama anak berada di dalam baby walker juga mempengaruhi penyimpangan dari penggunaan baby walker ${ }^{10}$. Penggunaan baby walker secara tepat dapat meningkatkan kemampuan motorik kasar dari anak karena ketika anak menggunakan baby walker, anak akan terbiasa berdiri dengan seluruh beban berat badannya bertumpu pada otot-otot ektremitas bawah anak tanpa menimbulkan trauma berupa resiko jatuh ${ }^{9}$.

Berdasarkan tabel $\mathrm{V}$ dapat dilihat perkembangan motorik kasar anak yang sesuai dengan usianya yaitu sebanyak 26 anak (78,8\%), sedangkan anak dengan perkembangan motorik yang meragukan diperoleh sebanyak 5 anak (15,2\%), dan hanya diperoleh 2 anak (6,0\%) yang mengalami perkembangan motorik yang menyimpang. Pemberian stimulasi, ras dan genetik mempunyai pengaruh penting dalam perkembangan motorik ${ }^{14}$ hal tersebut juga diperkuat oleh penelitian yang dilakukan oleh Chamidah yang menyebutkan bahwa perkembangan dan pertumbuhan anak dipengaruhi oleh faktor lingkungan atau eksternal, contoh faktor lingkungan yang banyak mempengaruhi pertumbuhan dan perkembangan anak adalah gizi, stimulasi, psikologis, dan sosial ekonomi ${ }^{1}$.

\section{Hubungan Ketepatan Penggunaan Baby Walker Terhadap Perkembangan Motorik Kasar Anak Usia 15-18 Bulan Di Denpasar Timur}

Berdasarkan hasil penelitian yang dilakukan dengan uji statistic Chi Square diperoleh hasil dari 33 anak yang menggunakan baby walker secara tepat sebanyak 75,8\% mempunyai perkembangan motorik kasar yang sesuai dengan usianya, sedangkan $3 \%$ anak yang penggunaan baby walkemya kurang tepat perkembangan motoriknya meragukan dan anak yang penggunaan baby walkemya menyimpang sebanyak $21,2 \%$ ternyata perkembanganan motoriknya beragam ada yang menyimpang, meragukan dan sesuai menurut usia. Secara statistik dapat dikatakan terdapat hubungan antara ketepatan penggunaan baby walker dengan perkembangan motorik kasar anak yaitu dengan nilai $p=0.000(p<0.05)$ hal ini berarti semakin tepat penggunaan baby walker maka perkembangan motorik kasar anak juga semakin sesuai menurut usianya. Hal ini sejalan dengan penelitian yang dilakukan oleh Dogan et.al di Fatih University Hospital Turki dengan jumlah subjek penelitian sebanyak 495 anak usia 2 bulan sampai 5 tahun diperoleh nilai $p=0,005$ dimana terdapat hubungan antara ketepatan penggunaan baby walker dengan perkembangan motorik anak $^{15}$ dan penelitian yang dilakukan Rahayu di Kelurahan Gebang Kecamatan Patrang Kabupaten Jember dengan jumlah subjek penelitian 44 anak usia 10-11 bulan diperoleh nilai $\mathrm{p}=0,003$ dimana anak yang menggunakan baby walker secara tepat memiliki perkembangan motorik yang normal ${ }^{3}$. Penggunaan baby walker yang tepat menurut The European Child Safety Alliance terbukti secara efektif dapat meningkatkan perkembangan motorik kasar anak, dari hasil penelitian tersebut juga diperoleh hasil jika anak yang menggunakan baby walker perkembangan motorik kasarnya dalam hal proses belajar berjalan akan lebih baik jika dibandingkan dengan anak yang tidak menggunakan baby walker .

Dari hasil penelitian ini menunjukkan anak yang menggunakan baby walker secara tepat perkembangan motorik kasarnya juga sesuai dengan usianya hal tersebut dikarenakan Baby walker dapat meningkatkan perkembangan motorik anak karena pada saat anak diletakkan di dalam baby walker maka anak akan mulai merasakan kakinya untuk memijak di lantai, hal tersebut menyebabkan anak akan terstimulasi untuk melakukan gerakan-gerakan seperti menapak, mempertahankan diri ketika berdiri, dan juga berjalan ${ }^{3}$. Ketika anak mulai terpapar stimulasi yang dihasilkan oleh penggunaan baby walker maka otot-otot ekstrimitas bawah pada anak seperti otot hamstring dan otot gastrocnemius akan sering berkontraksi dan terlatih sehingga dapat meningkatkan perkembangan motorik kasar anak ${ }^{3}$. Selain otot ekstremitas bawah, penggunaan baby walker yang tepat juga dapat memperkuat otot-otot core stability dari anak karena ketika anak sedang menggunakan baby walker, anak akan berada di posisi duduk tegak, dimana pada posisi ini tentunya membutuhkan kekuatan otot back dan juga otot abdomen agar anak dapat menjaga keseimbangan tubuhnya saat sedang menggunakan baby walker ${ }^{3}$. Penggunaan baby walker yang tepat dilakukan yaitu tidak lebih dari 5 jam perhari selama 2-5 bulan penggunaan dapat menyebabkan terjadinya peningkatan jumlah motor unit. Karena pada saat menggunakan baby walker secara rutin terjadi proses adaptasi yang terletak di korteks motorik yang ada di lobus frontalis dari otak akibat rangsang gerak yang dilakukan secara berulang ataupun melalui sebuah pola gerakan, sehingga hal itu akan menyebabkan korteks serebri akan menerima informasi rangsangan gerak dan segera merekam gerakan tersebut di lobus frontalis tepatnya di prefrontal sebagai memori jangka panjang ${ }^{16}$. Selain itu, penggunaan baby walker juga dapat menyebabkan meningkatnya protein kontraktil pada otot sehingga terjadi peningkatan konsentrasi ATP-PC dan juga enzim glikolisis ${ }^{17}$ oleh karena hal tersebut ketepatan penggunaan baby walker akan mempengaruhi performa atau kemampuan motorik kasar anak. Ketika otot anak menjadi lebih kuat dan stabil maka perkembangan motorik anak juga pasti akan meningkat dan sesuai dengan usianya ${ }^{3}$.

Dalam penelitian ini diperoleh juga anak yang penggunaan baby walkemya menyimpang atau kurang tepat, perkembangan motoriknya menjadi meragukan dan mengalami penyimpangan, hal tersebut karena penggunaan baby walker dalam jangka waktu yang terlalu lama atau dalam durasi yang panjang yang melebihi batas waktu yang ditentukan akan dapat menghilangkan efek positif yang ditimbulkan oleh baby walker dan akan berubah menjadi efek negatif ${ }^{18}$. Salah satu efek negatif yang diakibatkan oleh penggunaan baby walker yang kurang tepat atau mengalami penyimpangan yaitu cidera berupa deformitas kaki yang akan mempengaruhi perkembangan motorik kasar anak menjadi kurang optimal serta dapat menimbulkan trauma berupa trauma psikologis maupun trauma fisik jika penggunaan baby walker tidak dilakukan dengan tepat, hal tersebut juga tentunya akan merugikan kedua belah pihak yang terlibat didalamnya yaitu anak dan juga orang tua ${ }^{18}$.Anak yang menggunakan baby walker secara kurang tepat dalam penelitian ini diperoleh perkembangan motoriknya meragukan, hal tersebut disebabkan oleh kurangnya tingkat pengetahuan orang tua terkait penggunaan baby walker yang tepat dan benar serta kurangnya pengawasan orang tua selama anak berada di dalam baby walker ${ }^{10}$. Selain itu faktor yang juga dapat menyebabkan perkembangan motorik 
anak menjadi meragukan adalah faktor genetik, gizi anak ketika berada di dalam kandungan dan juga pola makan anak yang salah1. Dalam penelitian ini juga ditemukan 1 anak yang penggunaan baby walkemya menyimpang namun mempunyai perkembangan motorik yang sesuai, hal ini disebabkan karena anak tersebut mendapat asupan zat gizi yang sesuai dengan kebutuhannya yang tercermin dari status gizi anak tersebut. Nutrisi dapat dipenuhi dengan memberikan asupan zat gizi yang sesuai dan tepat bagi anak, maka anak akan tumbuh sesuai usianya serta menunjang perkembangan motorik dari anak ${ }^{19}$. Selain status gizi yang sesuai, yang dapat mempengaruhi perkembangan motorik anak menjadi normal yaitu dipengaruhi oleh faktor genetik keluarga dari anak tersebut ${ }^{1}$.

\section{SIMPULAN}

Berdasarkan penelitian yang telah dilakukan tentang hubungan ketepatan penggunaan baby walker terhadap perkembangan anak usia 15-18 bulan di wilayah kerja Puskesmas I Denpasar timur dapat disimpulkan bahwa terdapat hubungan yang signifikan antara ketepatan penggunaan baby walker dengan perkembangan motorik kasar anak. Semakin tepat anak menggunakan baby walker maka perkembangan motoriknya juga akan menjadi sesuai dengan usianya.

\section{DAFTAR PUSTAKA}

1. Chamidah AN. Deteksi Dini Gangguan Pertumbuhan dan Perkembangan Anak. journal of UNY. 2009;4(3)

2. Marilyn J et al. Injuries Associated With Infant Walkers. American Academy Of Pediatric. 2001;108(3)

3. Rahayu DA. Perbedaan Perkembangan motorik Kasar Anak Usia 10-11 Bulan Yang Menggunakan Baby Walker dan Metode Konvensional (Tatah) di Kelurahan Gebang Kecamatan Patrang Kabupaten Jember. [Skripsi]. Universitas Jember. 2010

4. Suhartini B. Tahap Perkembangan Motorik Anak. Jurnal FIK Universitas Negeri Yogyakarta. 2016

5. Sylvette $L$ et al. Vestibular Disorder in Children. International Journal Of Audiology. 2008;47(9)578-583

6. Kementrian Kesehatan Republik Indonesia. Pemantauan Pertumbuhan, Perkembangan, Dan Gangguan Tumbuh Kembang Anak. 2010. 1144/Menkes/Per/VIII/2010

7. Supartha $\mathrm{M}$ et al. Clumsiness. Jurnal Sari Pediatri Bagian IImu Kesehatan Anak Fakultas Kedokteran Universitas Udayana. 2009;11(1)

8. Siegel AC, Burton RV. Baby Walkers Delay Motor and Mental Developmental.Journal Developmental Behavior Pediatri. 2000;3(1)1-12

9. The European child safety alliance. European Child Safety Alliance and ANEC Joint Position Statement.[online] Available at: http://www.childsafetyeurope.org/publications/positionstatements/info/baby-walkers-positionstatement.pdf . 2010. [Accessed at 25 October 2018]

10. Rehmani R. Baby Walkers-Friend or Foe. Journal Pakistan Medical Association. 2010;6(11)891-892

11. Nariyanti E. Perbedaan Persepsi Antara Orang Tua Yang Menggunakan Baby Walker dan Orang Tua Yang Tidak Menggunakan Baby Walker Sebagai Stimulasi Tumbuh Kembang Balita Di Desa Banaran Tugu Trenggalek. [Skripsi]. Universitas Muhammadiyah Malang. 2016

12. Tan et al. Baby Walker: Gross Motor Developmental of The Child. Journal of Developmental. 2003; 130(4)671-681

13. Hasyim KF. Analisis Faktor Yang Memhubungan ketepatani Perilaku Orang Tua Menggunakan Baby Walker Untuk Anak Di Desa Sanggreman Kecamatan Rawalo Kabupaten Banyumas. [Skripsi]. Universitas Muhammadiyah Purwokerto. 2012

14. Lismadiana. Peran Perkembangan Motorik Pada Anak Usia Dini. Jurnal Pendidikan UNY.2006

15. Dogan DG et al. Baby Walker: A Perspective From Turkey. Journal Acta Pediatri. 2009;98(10)1658-1660

16. Reid, et al. Neuromuscular Adaptations To Eccentric Strength Training In Child. Journal Of Developmental Medecine \& Child Neurology. 2010;52 358-363

17. Kusuma DA. Hubungan ketepatan Pemberian Strengthening Exercise Ektrimitas Bawah Regio Foot Dan Ankle Terhadap Keseimbangan Statis Pada Anak Flat Foot Usia 6-9 Tahun Di SDN 2 Gonila Kartasura. [Skripsi]. Universitas Muhammadyah Surakarta.2017

18. Mete $\mathrm{M}$ et al. Baby Walker Use and Its Consequences In A Group of Turkish Children. Journal Arastirma. 2017;17(4)158-162

19. Utami RW. Faktor-Faktor Yang Memhubungan ketepatani Perkembangan Motorik Kasar Bayi Usia 6-24 Bulan di Klinik Baby Smile Kabupaten Karanganyar. [Tesis]. Universitas Sebelas Maret Surakarta.2015 